\title{
Trace elements contamination in an abandoned mining site in a semiarid zone
}

\author{
M.L. García-Lorenzo a , C. Pérez-Sirvent ${ }^{\mathrm{a}} *$, M.J. Martínez-Sánchez ${ }^{\mathrm{a},}$ J. Molina-Ruiz ${ }^{\mathrm{b}}$ \\ ${ }^{a}$ Department of Agricultural Chemistry, Geology and Pedology, Faculty of Chemistry, University of Murcia, Murcia Spain \\ ${ }^{\mathrm{b}}$ Department of Geography, Faculty of Geography, University of Murcia, Murcia Spain
}

ABSTRACT

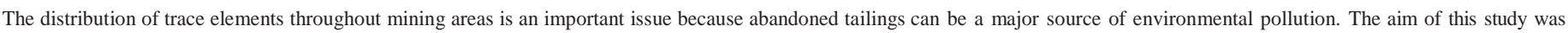

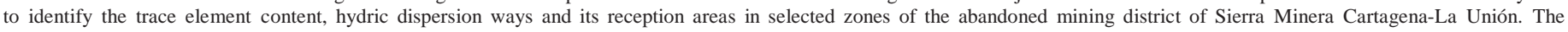

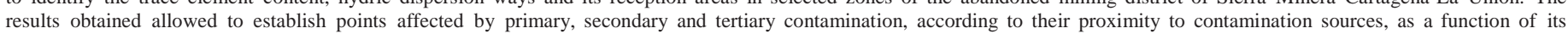
chemical and mineralogical composition. Applied GIS methodology allowed visualisation and confirmation of established conceptual model.

Keywords: Trace elements; Hydric dispersion; Soil contamination; Mining activities; Mapping

\section{Introduction}

Anthropogenic activities, such as mining and smelting of metal ores, have increased the prevalence and occurrence of trace element contamination at the Earth's surface. Specifically, opencast mining activities have a serious environmental impact on soils and water streams, having generated millions of tonnes of sulphide-rich tailings (Bhattacharya et al., 2006; Rodríguez et al., 2009). The adverse effects of mining activities in the environment have been addressed by many authors in many parts of the world (Chopin and Alloway, 2007; Gomes and Favas, 2006; Lee, 2003; Moreno et al., 2007; Navarro et al., 2004; Sun et al., 2006).

Nature of materials in mining areas, its mineralogical composition and its particle size distribution depends on the circumstances that have taken place, conditioning alteration processes caused by climatic agents.

Waste materials in modern mining exploitations use to present low reactivity to weathering processes, whilst in ancient exploita- tions, with mining and metallurgical activities, tailings are heteroge- neous, showing high trace element content, high degree of alteration and high reactivity. In addition, these areas present severe erosion problems caused by wind and water run-off, where soil and mine spoil texture, landscape topography and regional and local meteoro- logical conditions play an important role (Navarro et al., 2008).

Trace elements contained in the residues from mining and metallurgical operations are often dispersed, included in particulate material or in aqueous solution by wind and/or water after their

\footnotetext{
* Corresponding author. Tel.: +34868887449; fax: +34968364148.

E-mail address: melita@um.es (C. Pérez-Sirvent).
}

disposal (Lottermoser, 2007). According to transport process, three types of pollution could be established: i) Primary contamination, formed by residues placed close to the contamination sources;

ii) Secondary contamination, produced as a result of trace element dispersion out of its production areas, through water and wind;

iii) Tertiary contamination, which involves trace element mobilisation (Martínez-Sánchez et al., 2008).

In some cases, particularly where host rock is capable of buffering acid mine drainage, trace element content could be attenuated. As $\mathrm{pH}$ increases, the majority of the aqueous metal species tend to precipitate as hydroxide, oxyhydroxide, or hydroxysulfate phases (Kimball et al., 1994). Trace elements may also be adsorbed onto surfaces of these newly formed precipitates, removing the metals from solution (Chapman et al., 1983; Nordstrom, 1982).I Independent of chemical reaction, simple dilution could attenuate trace element concentration in the aqueous solution as well (Berger et al., 2000).

The aim of this study was to evaluate trace element content in four zones of the abandoned district of Sierra Minera Cartagena-La Unión. In addition, hydric dispersion of trace elements and reception areas has been studied in order to evaluate natural attenuation processes which could take place in the studied area.

\section{Material and methods}

\subsection{Studied area}

Sierra Minera of Cartagena-La Unión is located in the southeast of Murcia Region (Spain). It is a coastal saw with and approximate extension of 50 $\mathrm{km}^{2}$, limiting with the Mediterranean Sea in the south and with Campo de Cartagena in the north. The studied area was one of 

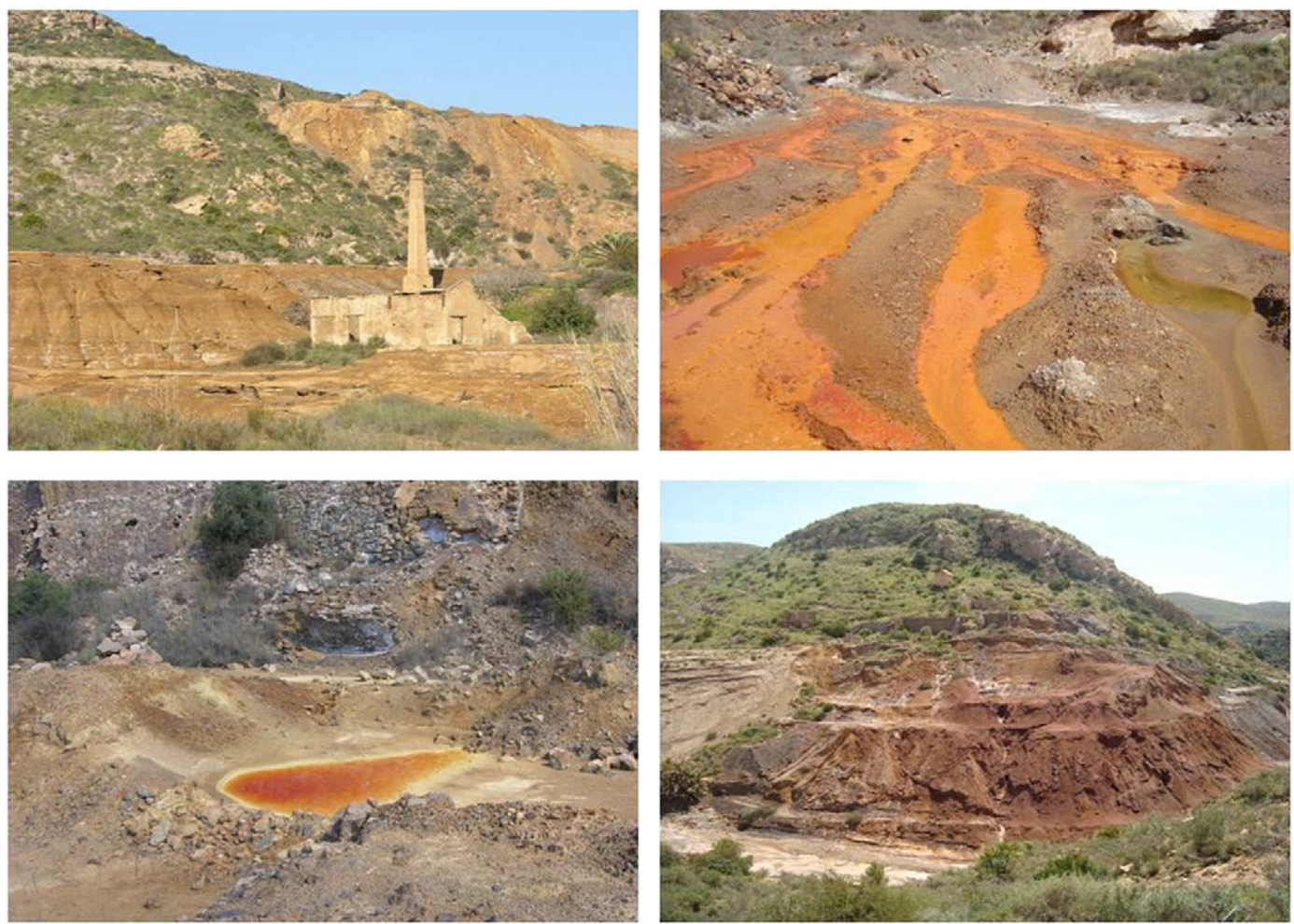

Fig. 1. Pictures of the studied area; a) abandoned exploitation: b and c) mine drainage; d) erosive processes in Zone D.

the main mining districts in the southeast of Spain (Martínez-Sánchez et al., 2008).

The average annual temperature is $17{ }^{\circ} \mathrm{C}$, and precipitation does not exceed $300 \mathrm{~mm}$, with occasional torrential rainfall, which frequently occurs between the end of summer and autumn. Perennial streams do not exist, and surface water consists of ephemeral streams (gullies), which are only operational during rainfall events. Stream flow is flashy and a significant amount of sediment is transported after long-lasting rainfall. Surface water drains both to the Mediterranean Sea and to the Mar Menor lagoon.

Sierra Minera of Cartagena-La Unión is the consequence of the Alpine ranges of the southernmost part of the Iberian Peninsula which constitutes de Betic Range. This region belongs to the Internal Zones of the Betic Range and three tectonic complex units can be identified from bottom to top (NevadoFilábride, Alpujárride and Maláguide complex). After the orogenic phase, an important erosive phase took

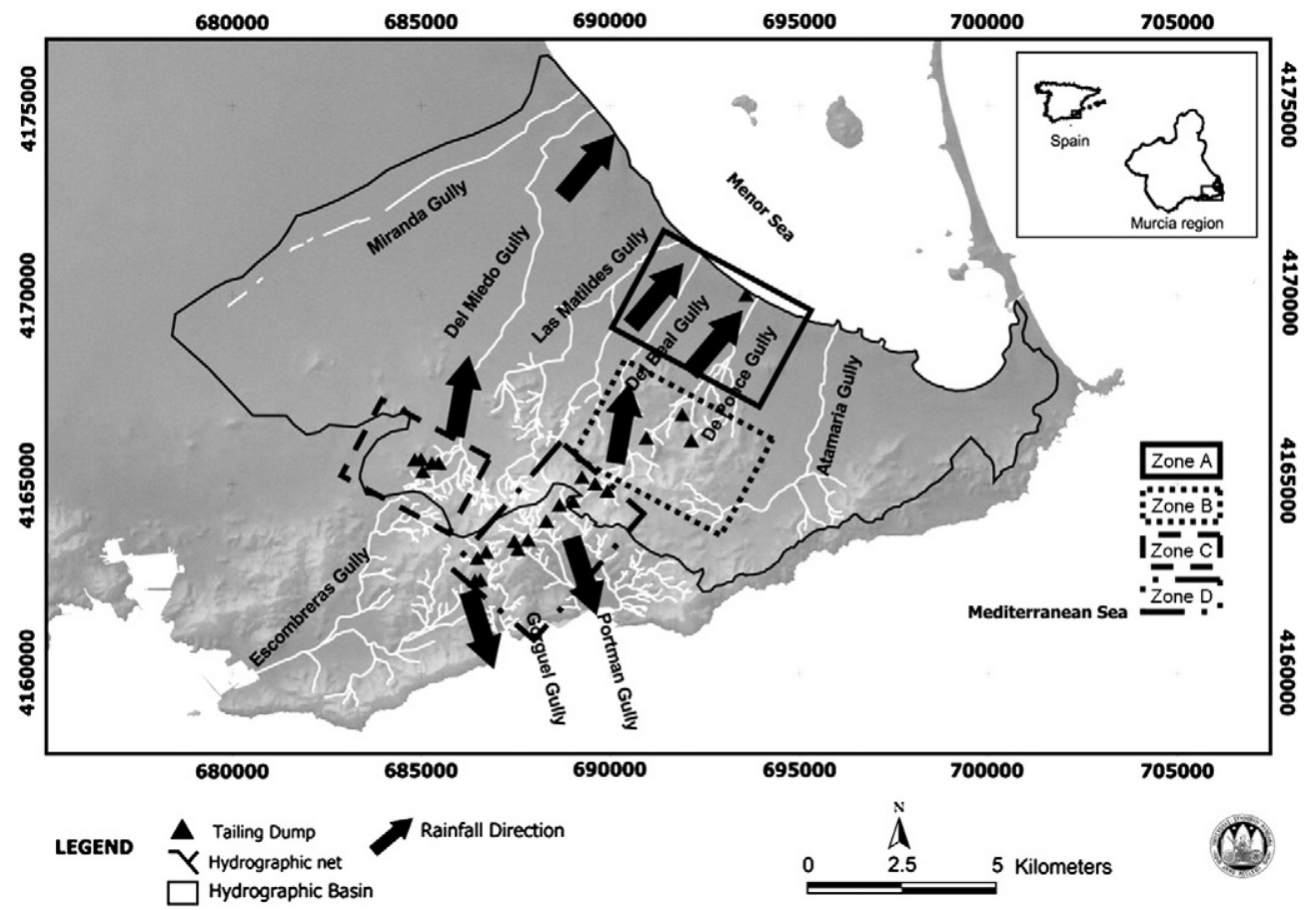

Fig. 2. Localisation of the studied zones and the hydrographic network where gullies are outlined. 
Table 1

Average analytical characteristics (mean \pm Std dev) in sediments from Zones A, B, C and D in each type of affection.

\begin{tabular}{|c|c|c|c|c|}
\hline Zone & $\mathrm{pH} \mathrm{H} \mathrm{H}_{2} \mathrm{O}$ & $\begin{array}{l}\text { EC (1:5) } \\
(\mathrm{dS} / \mathrm{m})\end{array}$ & $\begin{array}{l}\mathrm{CaCO}_{3} \\
(\%)\end{array}$ & $\begin{array}{l}\text { O.M. } \\
\text { (\%) }\end{array}$ \\
\hline \multicolumn{5}{|c|}{ Sources $(n=24)$} \\
\hline$A(n=5)$ & $5.3 \pm 0.9$ & $16.8 \pm 2.3$ & bdl & bdl \\
\hline$B(n=7)$ & $2.2 \pm 0.3$ & $9.6 \pm 1.3$ & bdl & bdl \\
\hline$C(n=8)$ & $2.5 \pm 0.2$ & $8.3 \pm 0.8$ & $0.3 \pm 0.02$ & bdl \\
\hline$D(n=4)$ & $2.0 \pm 0.3$ & $11.4 \pm 1.0$ & $0.5 \pm 0.03$ & bdl \\
\hline \multicolumn{5}{|c|}{ Primary $(n=29)$} \\
\hline$A(n=3)$ & $7.9 \pm 0.7$ & $8.7 \pm 5.2$ & $0.6 \pm 0.02$ & bdl \\
\hline$B(n=5)$ & $4.4 \pm 0.9$ & $3.2 \pm 2.5$ & bdl & bdl \\
\hline$C(n=8) D$ & $5.4 \pm 1.7$ & $3.4 \pm 1.8$ & bdl & bdl \\
\hline$(n=13)$ & $3.2 \pm 1.2$ & $51 \pm 3.7$ & bdl & bdl \\
\hline \multicolumn{5}{|c|}{ Secondary $(n=10)$} \\
\hline$A(n=4)$ & $8.2 \pm 0.04$ & $1.9 \pm 0.1$ & $19.1 \pm 4.0$ & $0.7 \pm 0.1$ \\
\hline B $(n=4)$ & $6.8 \pm 0.9$ & $1.9 \pm 0.9$ & $2.7 \pm 3.9$ & $0.6 \pm 0.2$ \\
\hline$D(n=2)$ & $4.9 \pm 2.3$ & $2.5 \pm 1.6$ & $4.4 \pm 6.3$ & $0.8 \pm 0.2$ \\
\hline \multicolumn{5}{|c|}{ Tertiary $(n=19)$} \\
\hline$A(n=8)$ & $7.9 \pm 0.3$ & $1.5 \pm 2.4$ & $39.8 \pm 26.9$ & $1.4 \pm 0.3$ \\
\hline$B(n=11)$ & $7.8 \pm 0.9$ & $1.1 \pm 0.8$ & $23.4 \pm 8.4$ & $1.7 \pm 0.1$ \\
\hline \multicolumn{5}{|l|}{ Control $(n=4)$} \\
\hline$A(n=1)$ & 8.7 & 0.3 & 45.2 & 2.2 \\
\hline B $(n=1)$ & 8.6 & 0.8 & 42.1 & 1.5 \\
\hline$C(n=1)$ & 8.2 & 0.6 & 26.7 & 1.1 \\
\hline $\mathrm{D}(\mathrm{n}=1)$ & 8.3 & 0.7 & 28.4 & 1.5 \\
\hline
\end{tabular}

place, together with a filling phase of generated basins. Afterwards, a distension and fracturing phase happened, together with magmatic processes. Finally, there was a postorogenic readjustement. These units are locally covered by pelitic rocks, including sandy and conglomeratic levels, and subvolcanic (rhyolitedacite and andesite) and volcanic events (alkaline basalt).

Soils in the studied area have been strongly affected by human activities, and according to FAO-1990 are classificated as Anthrosols, particularly Urbic Anthrosols(FAO, 1990).

The primary mineralisation of the area was succeeded by a strong secondary transformation process, resulting in the appearance of a large number of secondary minerals, while the supergene alteration processes affected both the primary mineralisation products and the host rocks (Navarro et al., 2008). The simple sulphide mineral assemblages of these deposits consist of galena, sphalerite, pyrite, marcasite, and chalcopyrite, together with trace amounts of other sulphides and sulphosalt minerals. Secondary minerals consist of smithsonite, hemimorphite, anglesite, cerussite, celestite, malachite, sulphur, goslarite, epsomite, gypsum, melanterite, szomolnokite, copiapite, carphosiderite, diadochite, hydrous iron oxide minerals, hematite and greenockite (Robles-Arenas and Candela, 2010).

As a result of mining activities, studied area showed a lot of contaminations sources formed by mining steriles, waste piles and foundry residues, 89 tailing dumps, 176 waste piles and two floatation dumps, discharging to the sea have been quantified (García-García, 2004). The extractive activity has produced morphological changes, producing variations in the drainage network with modification of natural slopes, and favouring erosion processes, increased by the scarce vegetation present in the studied area (Fig. 1).

\subsection{Materials and sampling method}

In order to select sampling points in the study area, four areas were established, and the sampling design was made to compare gradient of concentration and possible trace element mobilisation, according to ephemeral watercourses system (Fig. 2).

Table 2

Average mineralogical composition (\%) of the sediment samples in the study area.

\begin{tabular}{|c|c|c|c|c|c|c|c|c|c|c|c|c|c|}
\hline Zone & Phy & Fsp & Qtz & Gp & Jar & Hem & Gt & Aka & Gol & Alu & Cal & Dol & Amorphous \\
\hline \multicolumn{14}{|c|}{ Sources $(n=24)$} \\
\hline & 9 & 4 & 15 & 25 & 26 & 3 & 4 & 8 & 4 & - & - & - & 2 \\
\hline \multicolumn{14}{|c|}{ Primary $(n=29)$} \\
\hline$A(n=3)$ & 18 & 2 & 31 & 13 & 11 & 4 & 4 & 4 & 8 & 1 & - & - & 4 \\
\hline$B(n=5)$ & 23 & 3 & 23 & 8 & 17 & 8 & 6 & 4 & 3 & - & - & - & 5 \\
\hline$C(n=8)$ & 18 & 5 & 22 & 17 & 14 & 3 & 4 & 11 & 2 & 1 & - & - & 3 \\
\hline$D(n=13)$ & 14 & 7 & 21 & 9 & 23 & 5 & 6 & 5 & 3 & 2 & - & - & 5 \\
\hline \multicolumn{14}{|c|}{ Secondary $(n=10)$} \\
\hline$A(n=4)$ & 13 & 7 & 35 & - & - & 4 & - & - & - & - & 22 & 9 & 10 \\
\hline$B(n=4)$ & 19 & 3 & 32 & 5 & 9 & 4 & 4 & 13 & 5 & - & 4 & - & 2 \\
\hline$D(n=2)$ & 17 & 9 & 32 & 6 & 6 & 6 & 13 & 7 & 2 & - & - & - & 2 \\
\hline \multicolumn{14}{|c|}{ Tertiary $(n=19)$} \\
\hline$A(n=8)$ & 20 & 15 & 19 & - & 10 & 9 & - & - & 9 & - & 12 & 2 & 4 \\
\hline$B(n=11)$ & 21 & 3 & 39 & - & 5 & 4 & 2 & - & 3 & - & 13 & 8 & 2 \\
\hline \multicolumn{14}{|l|}{ Control $(n=4)$} \\
\hline$A(n=1)$ & 15 & 7 & 36 & - & - & 3 & - & - & - & - & 23 & 13 & 3 \\
\hline B $(n=1)$ & 15 & 15 & 33 & - & - & - & - & - & - & - & 28 & 8 & 1 \\
\hline$C(n=1)$ & 16 & 11 & 35 & - & - & 24 & - & - & - & - & 9 & 1 & 4 \\
\hline $\mathrm{D}(\mathrm{n}=1)$ & 13 & 15 & 33 & - & - & - & - & - & - & - & 29 & 8 & 1 \\
\hline
\end{tabular}

Phy: Phylosilicates; Fsp: Feldspars; Qtz: Quartz; Jar: Jarosite; Gt: Goethite; Aka: Akaganeite; Alu: Alunite; Cal: Calcite; Dol: Dolomite; Gol: Goldichite; Gp: Gypsum; Hem: Hematite. 
Table 3

Trace element concentration (mean \pm Std dev) in sediments from Zones A, B, C and D in each type of affection (mg/kg, except Fe in g/kg).

\begin{tabular}{|c|c|c|c|c|c|c|c|}
\hline Zone & $\mathrm{Zn}$ & $\mathrm{Pb}$ & $\mathrm{Cd}$ & $\mathrm{Fe}$ & As & $\mathrm{Cu}$ & Mn \\
\hline \multicolumn{8}{|c|}{ Sources $(n=24)$} \\
\hline $\mathrm{A}(\mathrm{n}=5)$ & $50,405 \pm 2078$ & $8317 \pm 395$ & $74 \pm 17$ & $211.2 \pm 91.1$ & $3627 \pm 366$ & $645 \pm 216$ & $3668 \pm 177$ \\
\hline $\mathrm{B}(\mathrm{n}=7)$ & $45,553 \pm 2456$ & $31,885 \pm 565$ & $82 \pm 9$ & $363.3 \pm 115.4$ & $4528 \pm 237$ & $379 \pm 121$ & $9242 \pm 673$ \\
\hline$C(n=8)$ & $39,942 \pm 1307$ & $5456 \pm 985$ & $73 \pm 21$ & $162.4 \pm 88.5$ & $5421 \pm 489$ & $619 \pm 176$ & $14,591 \pm 1003$ \\
\hline$D(n=4)$ & $54,366 \pm 977$ & $5086 \pm 725$ & $71 \pm 10$ & $221.2 \pm 83.0$ & $4610 \pm 478$ & $233 \pm 98$ & $2264 \pm 791$ \\
\hline \multicolumn{8}{|c|}{ Primary $(n=29)$} \\
\hline$A(n=3)$ & $20,619 \pm 5773$ & $3880 \pm 2345$ & $45 \pm 16$ & $136.5 \pm 92.1$ & $1117 \pm 766$ & $470 \pm 216$ & $3434 \pm 177$ \\
\hline $\mathrm{B}(\mathrm{n}=5)$ & $9994 \pm 708$ & $23,039 \pm 868$ & $49 \pm 20$ & $268.2 \pm 88.8$ & $2038 \pm 1093$ & $521 \pm 289$ & $7165 \pm 145$ \\
\hline$C(n=8)$ & $14,799 \pm 1785$ & $3051 \pm 629$ & $46 \pm 11$ & $107.6 \pm 41.7$ & $1277 \pm 949$ & $527 \pm 314$ & $3365 \pm 432$ \\
\hline $\mathrm{D}(\mathrm{n}=13)$ & $9889 \pm 734$ & $9484 \pm 1727$ & $32 \pm 16$ & $163.4 \pm 31.5$ & $2354 \pm 947$ & $482 \pm 321$ & $1460 \pm 90$ \\
\hline \multicolumn{8}{|c|}{ Secondary $(n=10)$} \\
\hline$A(n=4)$ & $7539 \pm 187$ & $1422 \pm 141$ & $28 \pm 12$ & $96.2 \pm 17.6$ & $673 \pm 292$ & $265 \pm 48$ & $2147 \pm 133$ \\
\hline$B(n=4)$ & $5882 \pm 925$ & $1972 \pm 764$ & $31 \pm 21$ & $201.6 \pm 87.7$ & $572 \pm 77$ & $141 \pm 23$ & $3114 \pm 871$ \\
\hline$D(n=2)$ & $5223 \pm 1109$ & $1954 \pm 936$ & $19 \pm 6$ & $100.4 \pm 52.1$ & $550 \pm 321$ & $195 \pm 81$ & $2850 \pm 252$ \\
\hline \multicolumn{8}{|c|}{ Tertiary $(n=19)$} \\
\hline$A(n=8)$ & $2481 \pm 705$ & $779 \pm 403$ & $13 \pm 9$ & $87.6 \pm 5.5$ & $439 \pm 134$ & $407 \pm 155$ & $7257 \pm 580$ \\
\hline $\mathrm{B}(\mathrm{n}=11)$ & $3220 \pm 1151$ & $871 \pm 503$ & $11 \pm 5$ & $147.8 \pm 5.8$ & $420 \pm 397$ & $304 \pm 188$ & $10,502 \pm 683$ \\
\hline \multicolumn{8}{|c|}{ Control $(n=4)$} \\
\hline$A(n=1)$ & 40 & 14 & 0.3 & 6.2 & 6 & 12 & 350 \\
\hline $\mathrm{B}(\mathrm{n}=1)$ & 30 & 10 & 0.6 & 8.5 & 8 & 16 & 197 \\
\hline$C(n=1)$ & 85 & 17 & 0.3 & 12.1 & 71 & 11 & 212 \\
\hline $\mathrm{D}(\mathrm{n}=1)$ & 67 & 10 & 0.3 & 7.3 & 12 & 14 & 200 \\
\hline
\end{tabular}

Table 4

Statistic correlations between minerals and trace element concentration in sediment samples.

\begin{tabular}{|c|c|c|c|c|c|c|}
\hline $\mathrm{Zn}$ & $\mathrm{Pb}$ & Cd & $\mathrm{Fe}$ & As & $\mathrm{Cu}$ & Mn \\
\hline Phy (-0654) & Jar (0.791) & Phy (-0.640) & \multirow[t]{4}{*}{ Phy $(-0.600)$} & Jar $(0.811)$ & Gp (0.765) & \multirow[t]{4}{*}{$\operatorname{Dol}(-0.538)$} \\
\hline Gp (0.666) & Phy $(-0.587)$ & Cal $(-0.685)$ & & \multirow{3}{*}{ Cal (-0.754) } & Jar (0.652) & \\
\hline Gol (0.531) & Cal $(-0.679)$ & $\operatorname{Dol}(-0.619)$ & & & Alu (0.549) & \\
\hline Dol (-0.688) & Dol $(-0.705)$ & & & & Cal $(-0.654)$ & \\
\hline
\end{tabular}

Zone A: is the farthest area from Sierra Minera, showing a depressed topographical situation. This zone is affected by two gullies (El Beal and Ponce), discharging both of them in the Mar Menor lagoon.

Zone B: this area showed a rugged topography and is drained by numerous gullies, which finally form El Beal and Ponce gullies. Mining activities have caused geomorphologhical changes, favour- ing ravine apparition.

Zone C: this area corresponds to Cabezo Rajao, which acts like a big contamination source, supplying particulate material and acid mine drainage. This zone showed strong slopes and presents intense erosion processes.
Zone D: nine tailing dumps have been identified. Torrential rainfalls in the area increase erosion processes, favoured by the scant vegetation.

Sampling points have been selected according to their proximity to the contamination sources, establishing three types of samples: sediment samples located in areas next to the contamination source, sediment samples located in the dispersion paths and sediment samples located in areas minimally affected by the contaminants.

Sediment samples were collected together with water samples. As a result, 86 samples were collected as follows: 24 samples were collected in tailing dumps (contamination sources), 58 samples were collected along the gully watercourses and finally, 4 control

Table 5

Trace element concentration (mg/L, except As in $\mu \mathrm{g} / \mathrm{L})$ in superficial water samples.

\begin{tabular}{|c|c|c|c|c|c|c|c|c|c|c|}
\hline Zone & $\mathrm{pH}$ & $\mathrm{Zn}$ & $\mathrm{Pb}$ & $\mathrm{Cd}$ & $\mathrm{Fe}$ & As & $\mathrm{Cu}$ & $\mathrm{Mn}$ & $\mathrm{SO}_{4}^{2-}$ & $\mathrm{CO}_{3}^{2-}$ \\
\hline \multicolumn{11}{|l|}{ Sources $(n=24)$} \\
\hline $\mathrm{A}(\mathrm{n}=5)$ & $3.0 \pm 0.2$ & $11,000 \pm 153$ & $8.6 \pm 5.1$ & $4.9 \pm 3.4$ & $19.4 \pm 6.6$ & $20.9 \pm 11.3$ & $11.7 \pm 6.2$ & $5040 \pm 196$ & $61,326 \pm 205$ & bdl \\
\hline $\mathrm{B}(\mathrm{n}=7)$ & $3.0 \pm 0.4$ & $9883 \pm 551$ & $9.5 \pm 3.8$ & $7.1 \pm 2.9$ & $7.3 \pm 1.4$ & $13.6 \pm 7.9$ & $14.5 \pm 8.2$ & $2099 \pm 13$ & $32,224 \pm 127$ & bdl \\
\hline $\mathrm{C}(\mathrm{n}=8)$ & $2.1 \pm 0.2$ & $905 \pm 248$ & $5.8 \pm 2.9$ & $100.3 \pm 9.2$ & $5900 \pm 6.2$ & $11676.1 \pm 503.5$ & $12.9 \pm 5.1$ & $175 \pm 19$ & $53,650 \pm 197$ & bdl \\
\hline Pripladiy $(n 4) 24)$ & $1.9 \pm 0.3$ & $430 \pm 48$ & $0.63 \pm 0.1$ & $16.2 \pm 8.9$ & $1860 \pm 9.3$ & $15319.2 \pm 21.1$ & $76.4 \pm 23.5$ & $270 \pm 146$ & $21,555 \pm 201$ & bdl \\
\hline$A(n=3)$ & $3.3 \pm 0.7$ & $4000 \pm 772$ & $3.1 \pm 1.7$ & $3.5 \pm 0.4$ & $9.2 \pm 2.6$ & $7.6 \pm 2.2$ & $9.7 \pm 2.2$ & $2040 \pm 197$ & $41,326 \pm 267$ & bdl \\
\hline$B(n=5)$ & $3.9 \pm 0.1$ & $1015 \pm 331$ & $4.9 \pm 1.5$ & $4.5 \pm 2.2$ & $1.8 \pm 0.9$ & $2.0 \pm 1.0$ & $0.6 \pm 0.3$ & $75 \pm 39$ & $17,001 \pm 195$ & bdl \\
\hline$C(n=8)$ & $4.2 \pm 0.4$ & $20,000 \pm 850$ & $4.2 \pm 2.7$ & $66.1 \pm 9.7$ & $0.7 \pm 0.1$ & $10.3 \pm 3.5$ & $2.3 \pm 0.2$ & $1600 \pm 432$ & $32,904 \pm 561$ & bdl \\
\hline $\mathrm{D}(\mathrm{n}=13)$ & $2.4 \pm 0.2$ & $6450 \pm 461$ & $3.6 \pm 0.4$ & $42.2 \pm 14.4$ & $268 \pm 84.1$ & $3.9 \pm 0.9$ & $3.4 \pm 0.5$ & $1110 \pm 109$ & $9140 \pm 231$ & bdl \\
\hline \multicolumn{11}{|c|}{ Secondary $(n=10)$} \\
\hline$A(n=4)$ & $7.1 \pm 0.2$ & $69 \pm 12$ & bdl & $0.6 \pm 0.1$ & bdl & $2.3 \pm 0.3$ & bdl & bdl & $1987 \pm 123$ & $102 \pm 12$ \\
\hline$B(n=4)$ & $6.3 \pm 0.3$ & $0.5 \pm 0.1$ & bdl & $1.6 \pm 0.2$ & bdl & $1.1 \pm 0.4$ & bdl & bdl & $4087 \pm 57$ & bdl \\
\hline$D(n=2)$ & $4.8 \pm 0.2$ & $180 \pm 45$ & $0.9 \pm 0.1$ & $0.4 \pm 0.2$ & bld & $3.7 \pm 1.2$ & bdl & $12 \pm 2$ & $1392 \pm 177$ & bdl \\
\hline \multicolumn{11}{|l|}{ Tertiary $(n=19)$} \\
\hline$A(n=8)$ & $7.3 \pm 0.1$ & $30 \pm 13$ & bdl & $0.8 \pm 0.1$ & bdl & bdl & bdl & $11.5 \pm 0.4$ & $378 \pm 29$ & $1593 \pm 107$ \\
\hline $\mathrm{B}(\mathrm{n}=11)$ & $7.2 \pm 0.1$ & $11 \pm 0.9$ & bdl & bdl & bdl & bdl & bdl & $6.6 \pm 2.5$ & $111 \pm 80$ & $1099 \pm 23$ \\
\hline
\end{tabular}




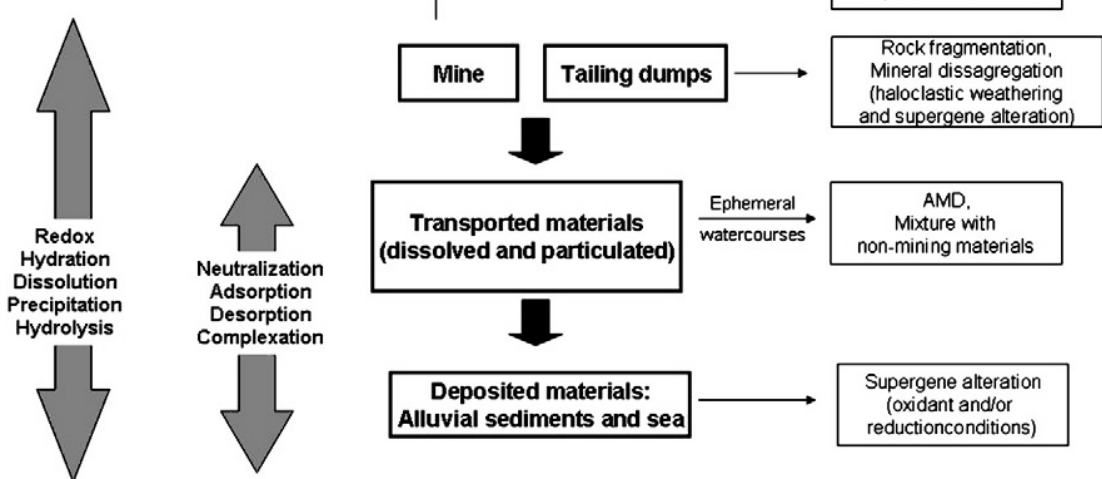

Fig. 3. Main processes affecting materials in areas with mining influence.

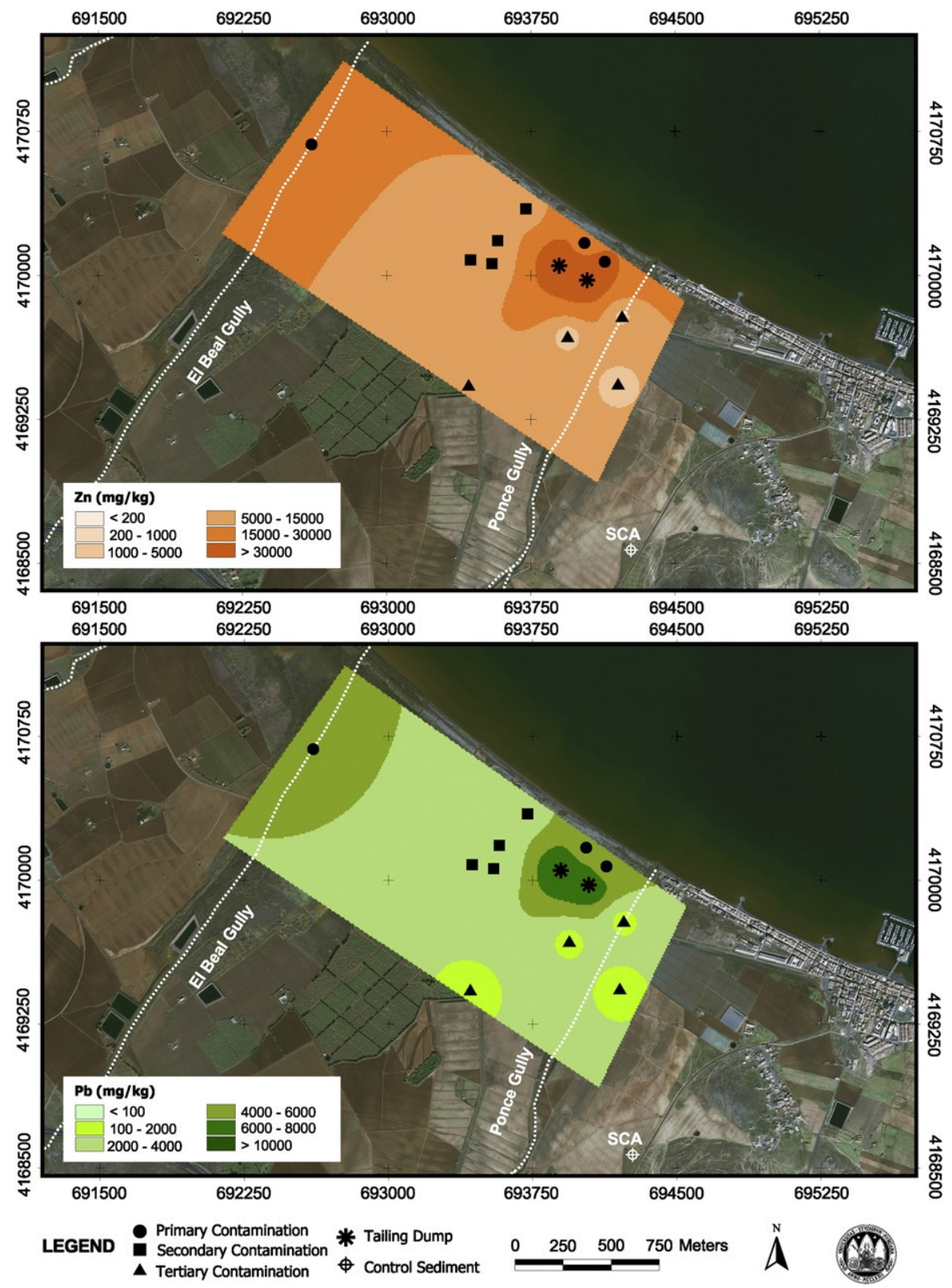

Fig. 4. Spatial distribution of $\mathrm{Zn}$ and $\mathrm{Pb}$ in $\mathrm{Zone} \mathrm{A}$. 

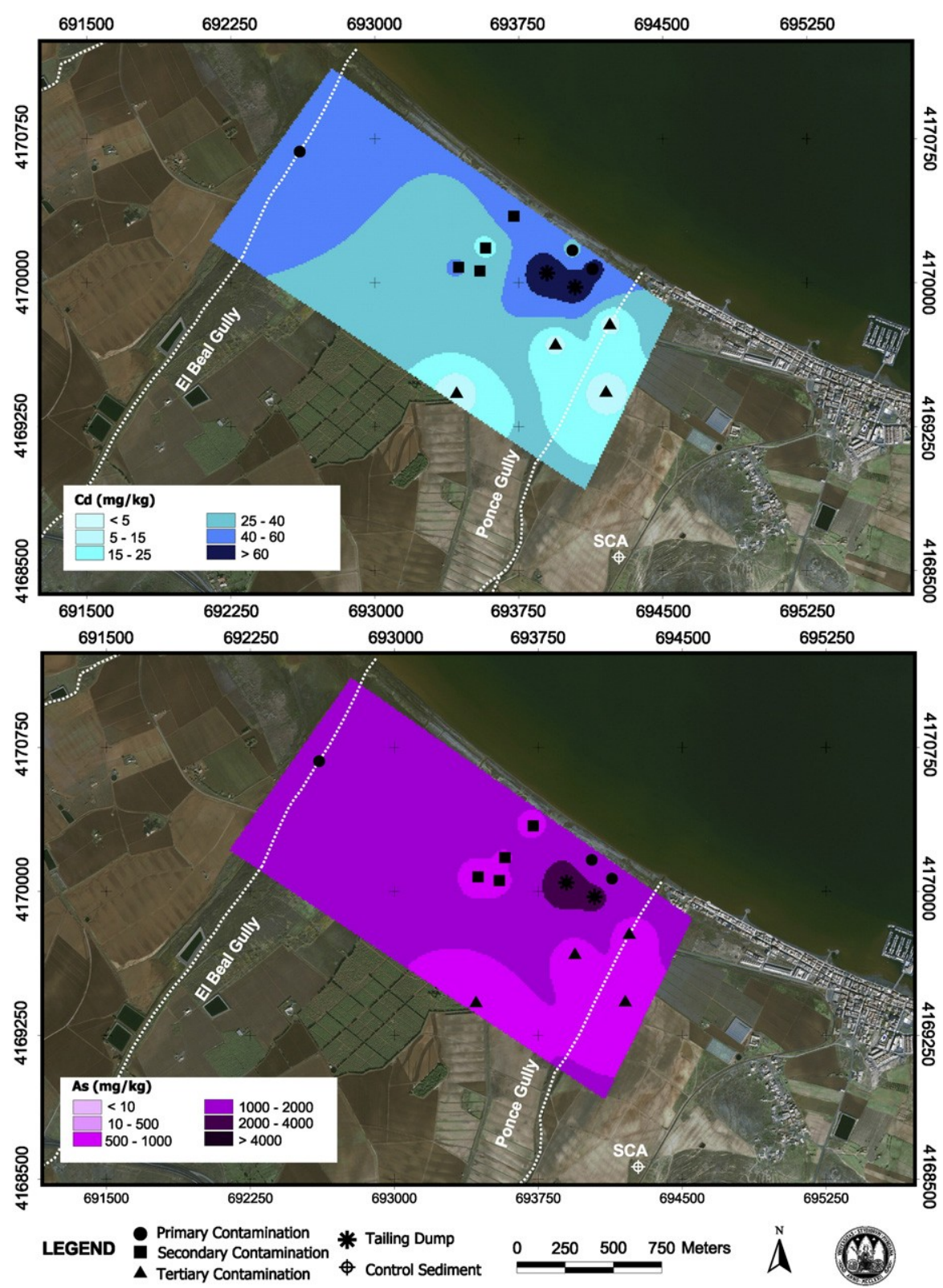

Fig. 5. Spatial distribution of Cd and As in Zone A.

sediments, non-affected by mining activities were also sampled. Control sediments were sampled and processed in the same way as the other samples. The background sites showed similar character- istics to other samples, that is, the same topographical location, similar soil physical characteristics, similar water regimen and similar parent material and soil forming processes (Swingedouw and Crépin, 2008).

\subsection{Sample preparation and methodology}

Sediment samples were collected at $0-30 \mathrm{~cm}$ depth, air-dried and sieved through a $2 \mathrm{~mm}$ screen for general analytical determinations. In addition, water samples were collected, at the same site as the sediment after a rain episode, filtered and stored for posterior analysis.

The $\mathrm{pH}$ was determined in a 1:5 (w/v) suspension of sediment in Milli-Q quality water using a Crison GLP21 pH metre. Electrical conductivity (EC) (dS m${ }^{-1}$ at $25^{\circ} \mathrm{C}$ ) was also measured using a Crison GLP31 metre in the extracts obtained by filtering the $1: 5$ suspensions through a $0.45 \mu \mathrm{m}$ cellulose acetate disc filter. The $\mathrm{pH}$ and electrical conductivity were also determined in water samples. Equivalent calcium carbonate (\%) was determined in sediment samples by the volumetric method using a Bernard calcimeter. Organic carbon was determined by sulfochromic oxidation (Nelson and Sommers, 1982), according to the NF X 31-109 standard (AFNOR, 1993).

Mineralogical analysis of sediment samples was made by $\mathrm{X}$ Ray Diffraction (XRD) analysis using $\mathrm{Cu}-\mathrm{K} \alpha$ radiation with a PW3040 Philips Diffractometer. X-powder software was used to analyse the X- ray diffraction diagrams obtained by the crystalline powder method. The powder diffraction file (PDF2) database was used for peak identification, taking into account that the determination of minerals from sediments by XRD analysis is not accurate below a limit of $5 \%$ of the total weight in a sample (depending on the crystallinity of individual minerals) (Martín, 2004).

To determine total trace element content, sediments were first ground to a fine powder using a zirconium ball mill. $0.1 \mathrm{~g}$ of sediment sample was placed in Teflon vessels and $5 \mathrm{ml}$ of concentrated HF acid solution, $200 \mu \mathrm{l}$ of concentrated $\mathrm{HNO}_{3}$ acid solution and $5 \mathrm{ml}$ of water 


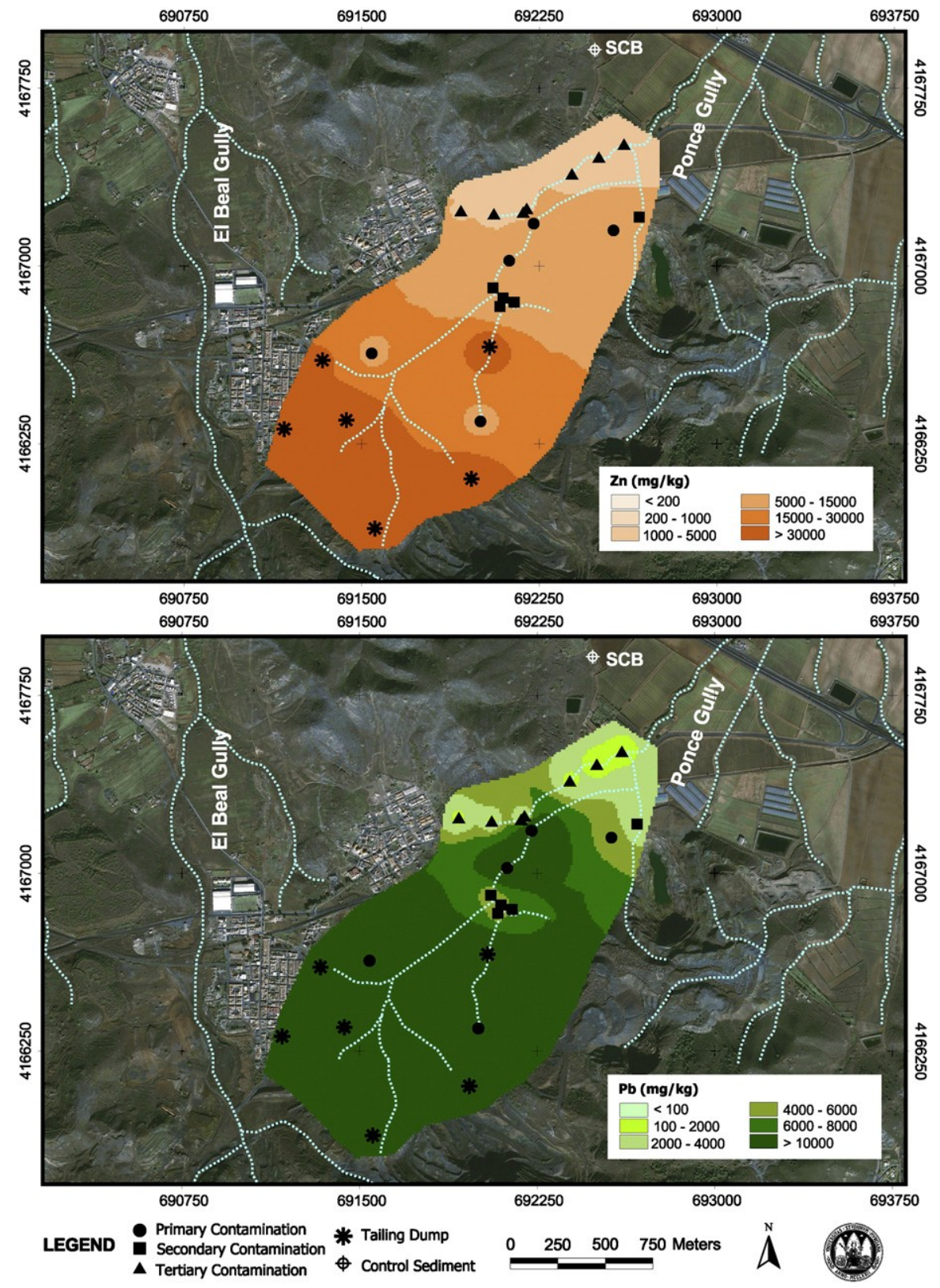

Fig. 6. Spatial distribution of $\mathrm{Zn}$ and $\mathrm{Pb}$ in Zone $\mathrm{B}$.

were added. When digestion was complete $(15 \mathrm{~min}$ at $1000 \mathrm{~W}$ in a Milestone ETHOS PLUS microwave oven), the samples were trans- ferred to a volumetric flask and brought to $50 \mathrm{ml}$.

The $\mathrm{Zn}$ and $\mathrm{Fe}$ content in water and sediment samples were determined by flame atomic absorption spectrometry (FAAS) using a PerkinElmer 1100B Atomic Absorption Spectrophotometer. The $\mathrm{Pb}, \mathrm{Cd}, \mathrm{Cu}$ and $\mathrm{Mn}$ contents in sediment and water samples were determined by electrothermal atomization atomic absorption spec- trometry (ETAAS) using an Unicam 929 AAS spectrometer. Finally, the As content was measured by atomic fluorescence spectrometry using an automated continuous flow hydride generation spectrometer (PSA Millenium Merlin 10055 for As). The reliability of the results was verified by analysing a standard reference material (SRM 2711 Montana Soil).

\subsection{Statistical analysis}

A correlation matrix was used to identify the possible relationship between trace element content and mineralogical composition of sediment samples. The starting point for the multivariant analysis was triangular matrices formed by measurement of the Pearson's correlation coefficients obtained by dividing the covariance by the product of the typical variations. In this way the relationships were easier to interpret since only values between +1 and -1 can be taken.

\subsection{Geographic Information System (GIS) methodology}

The sampling points, obtained by GPS, were integrated to create a database in which the coordinates were included. With the ortho- photos and the Digital Terrain Model (DTM), a restitution of the hydrographical net was carried out. After that, spatial interpolation and GIS mapping techniques were employed to produce spatial distribution maps for target elements. For this purpose, ArcGIS v.9 software was used. To make distribution maps, kriging was chosen to interpolate, owing to its several favourable properties. To minimise errors, the six nearest neighbour method was used. The last step was 


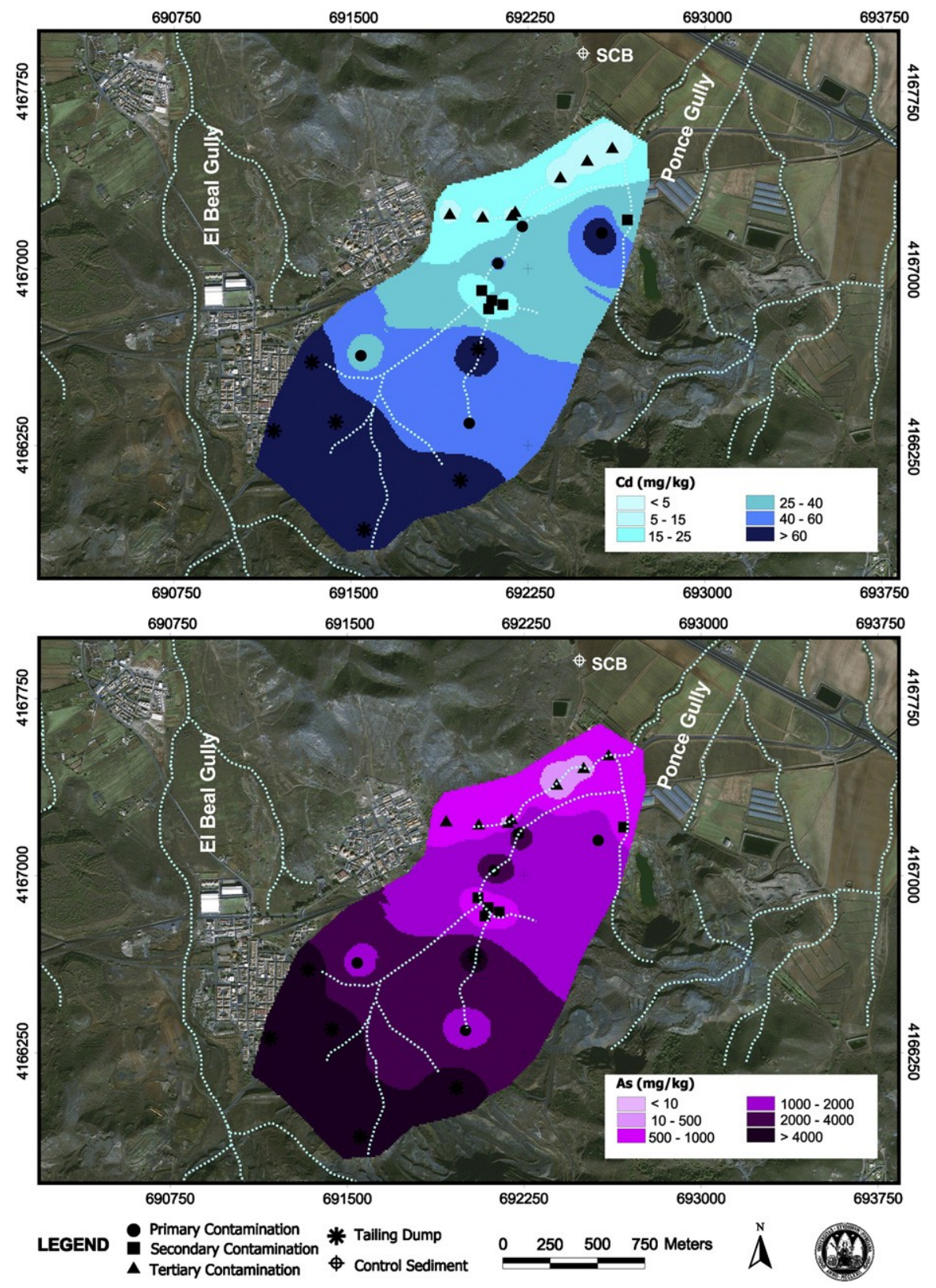

Fig. 7. Spatial distribution of Cd and As in Zone B.

to reclassify the original maps, establishing 6 intervals as a function of trace element concentration.

\section{Results and discussion}

\subsection{Chemical analysis}

\subsubsection{Particulated phase}

Sediment samples collected in contamination sources showed acidic $\mathrm{pH}$ and high electrical conductivity (Table 1 ). The average mineralogical composition consists mainly of sulphates, such as jarosite, gypsum, alunite and goldichite (Table 2). In addition, sediments from contamination sources showed high trace element content (Table 3). The maximum values correspond to tailing dump samples.

Points affected by primary contamination are located close to the contamination sources. Their mineralogical composition is charac- terised by jarosite, gypsum and other sulphates, such as goldichite. These sediments showed acidic $\mathrm{pH}$ and high trace element concen- tration (Tables 1-3). Sediments affected by secondary contamination have been mixed with parent material during transport processes. In addition, dilution effect during transport could attenuate trace element concentration. Even if a natural attenuation process takes place, trace element concentration is high. Mineralogical composition of these sediments consists of sulphates, phyllosilicates, feldspars and quartz. In addition, $\mathrm{pH}$ values are higher than samples affected by primary contamination (Tables $1-3$ ).

In sediments affected by tertiary contamination tailing influence is less representative, probably because of transported materials have been mixed with surrounding materials, with a carbonated nature, taking place an attenuation process, that is, $\mathrm{pH}$ increase and metal concentra- tions decrease. Presumably the presence of $\mathrm{CaCO}_{3}$ in some samples was

due to the reaction of the $\mathrm{CO}_{2}$ and $\mathrm{Ca}^{2+}$ released from the calcic plagioclases (Navarro et al., 2008). In addition, dilution has attenuated trace element concentration, independent of chemical reaction.

Mineralogical composition of these sediments is characterised by calcite and dolomite and then, their $\mathrm{pH}$ values are basic. Moreover, jarosite and alunite are not present in these samples. Jarosite and 


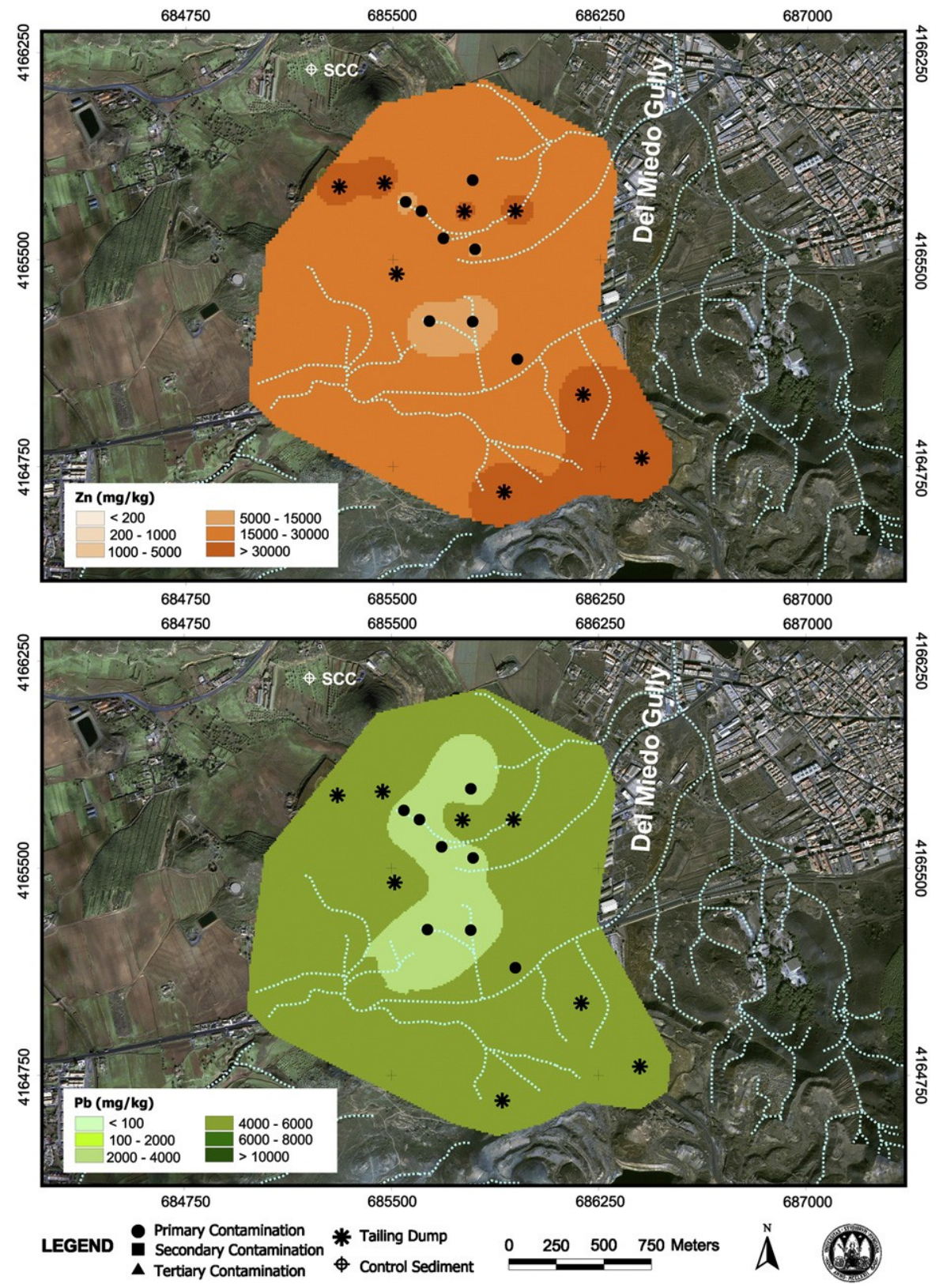

Fig. 8. Spatial distribution of $\mathrm{Zn}$ and $\mathrm{Pb}$ in Zone C.

other mineral sulphate formation depends on $\mathrm{pH}$ and sulphate content. Particularly, jarosite and other sulphate minerals are minerals originated in the supergenic alteration processes that occur in the tailings and sediments affected by primary contamination. However, due to the dilution effect caused by the presence in the sediments of a large amount of materials without mining influence, the concentration is below the limit of XRD and they are not identified. Trace element content in these sediments is lower than those determined in points affected by primary or secondary contamination (Tables $1-3)$.

In areas affected by sulphide mining activities, a neutralisation process could take place if mining materials are in contact with minerals able to generate alkalinity, especially with carbonates and in a lower content, with hydroxides or aluminosilicate minerals (Banks et al., 1997). Neutralisation process unchains a series of reactions of trace element mitigation, since many of them tend to precipitate when the $\mathrm{pH}$ increases (Lottermoser, 2007).

The presence of carbonated minerals in sufficient quantity to neutralise the acidity produced by the dissolution of sulphides avoids the generation of acid waters. However, in places without carbonates,
$\mathrm{pH}$ buffering is carried out by aluminosilicates. These minerals are dissolved more slowly than carbonates and its neutralisation capacity is much more reduced (Asta, 2011). If carbonated minerals have been completely dissolved and aluminosilicate mineral buffering potential is not sufficiently effective, $\mathrm{pH}$ value could decrease (4.0-4.5) and precipitation of aluminium hydroxides or sulphates, such as alunite or gibbsite, takesplace.

Sediments taken as control present basic $\mathrm{pH}$ value, high calcium carbonate and organic matter content. Mineralogical composition is characterised by calcite, dolomite, phyllosilicates and feldspars, and trace element content is low, due to geogenic values (Pérez-Sirvent et al., 2009) in the studied area (Tables 1-3) (García-Lorenzo, 2009). A correlation analysis was carried

out between mineralogical composition and trace element content. Obtained results suggested that phyllosilicates were negatively correlated with $\mathrm{Zn}, \mathrm{Pb}, \mathrm{Cd}$ and Fe. In a similar way, calcitecontent was negatively correlated with Pb, Cd, As and $\mathrm{Cu}$ content, and dolomite percentage was negatively correlated with $\mathrm{Zn}$, $\mathrm{Pb}, \mathrm{Cd}$ and $\mathrm{Mn}$. That is, the presence of carbonates and phyllosilicates in the mineralogical composition corresponds to lower trace element content. 


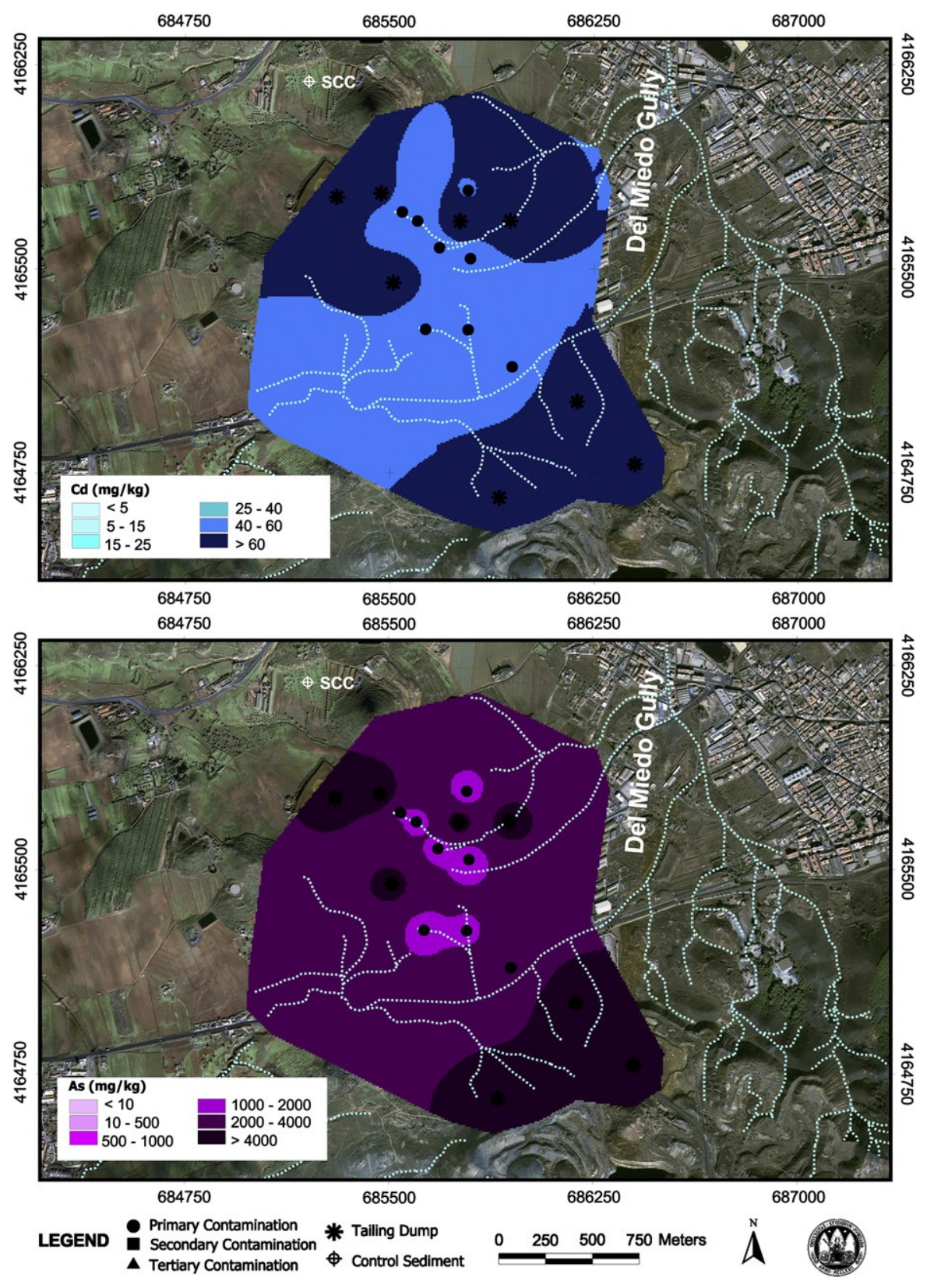

Fig. 9. Spatial distribution of Cd and As in Zone C.

On the other hand, sulphates, like gypsum, jarosites or alunite, were positively correlated with some trace elements, particularly jarosite content was positively correlated with $\mathrm{Pb}$, $\mathrm{As}$ and $\mathrm{Cu}$, gypsum was positively correlated with $\mathrm{Zn}$ and $\mathrm{Cu}$ and alunite was positively correlated with $\mathrm{Cu}$ content in the studied samples (Table 4).

\subsubsection{Dissolved phase}

Superficial water samples collected in contamination sources and those placed close to tailing dumps and then affected by primary contamination, showed acidic $\mathrm{pH}$, high trace element content and high percentage of dissolved sulphates. On the other hand, superficial waters affected by secondary contamination showed lower concen- tration of trace elements, higher $\mathrm{pH}$ values and lower dissolved sulphates than those affected by primary contamination. Dissolved carbonates are present in waters affected by tertiary contamination and could aid to trace element precipitation. In these waters, trace element concentration is low and $\mathrm{pH}$ is neutral or basic. The stabilisation of trace elements with carbonates agrees with the low contents of metals in superficial waters (Table 5).

\subsubsection{Summary of weathering, transport and deposition processes in the studied area}

Physical weathering comprises several processes leading to the mechanical fracture of rocks which in turn favours the chemical weathering of rock minerals by hydration, hydrolysis and oxidationreduction reactions. Weathering intensity depends on chemical composition, climate conditions, rock type, topography and time (Rajamani et al., 2009). The most important weathering processes in the studied area are oxidation-reduction, hydration, hydrolysis and dissolution-precipitation processes.

Mining activities in the studied area have produced intense morphological changes, modifying drainage network and natural slopes, taking place remontant erosion processes. In addition, torrential rainfall and the scant vegetation present in the studied area amplify the erosive processes. 

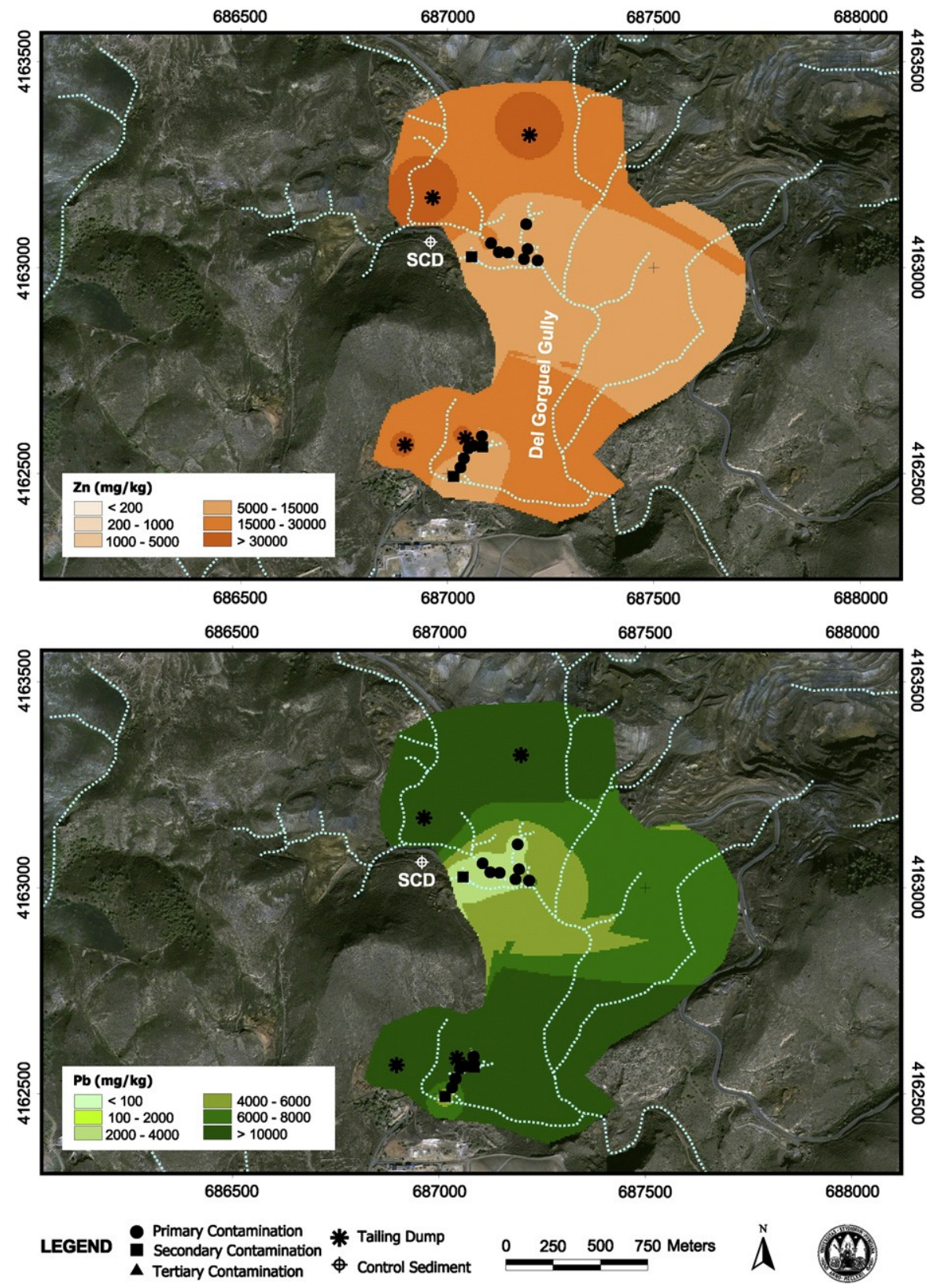

Fig. 10. Spatial distribution of $\mathrm{Zn}$ and $\mathrm{Pb}$ in Zone $\mathrm{D}$.

During the transport phase dissolution and hydration processes acquire more importance and weathering products are mobilised as dissolved or particulate phases. Materials from supergene alteration, like sulphates, oxides, oxyhydroxides, together with clay minerals are transported as well as dissolved species. In addition, materials non- affected by supergene alteration, like parent material fragments or resistantminerals, arealsotransported.

When kinetic energy of the system diminishes, sedimentation processes happen. Dissolved and particulate materials are deposited, taking place heterogeneous chemical reactions. Soils with a carbon- ated nature (calcic and petrocalcic Xerosols) are present in the influence zone of Sierra Minera, and some of them are located in gullies inundation area, receiving materials from mining areas.

Fig. 3 showed the conceptual model of main processes affecting materials in areas with mining influence in the studied area. These processes could take place in some metres or at a distance of more than $50 \mathrm{~km}$, depending on topography of collected sample and on geology of the studied area. In some cases there is a short space between mine and tailing, and as a result, processes could be superimposed, being very difficult to decide contamination degree.

\subsection{GIS results}

GIS application allows representing established classification, that is, points affected by primary $(\bullet)$, secondary $(\boldsymbol{\bullet})$ and tertiary contamination $(\boldsymbol{\Delta})$ by trace elements, together with contamination sources $(*)$ and control sediments (SC). The obtained maps permit to evaluate trace element dispersion in the studied area. In addition, $\mathrm{Zn}, \mathrm{Pb}, \mathrm{Cd}$ and As contents have been represented in these maps in order to understand trace element dispersion in the studied zones.

\subsubsection{Trace element dispersion conceptual model in Zone A}

In this area, trace elements are transported from tailing dumps located in the Sierra Minera and from a tailing dump located close to the beach (Figs. 4 and 5). In addition, transported materials are mixed with soils with a carbonate nature, located in the surrounding areas. 


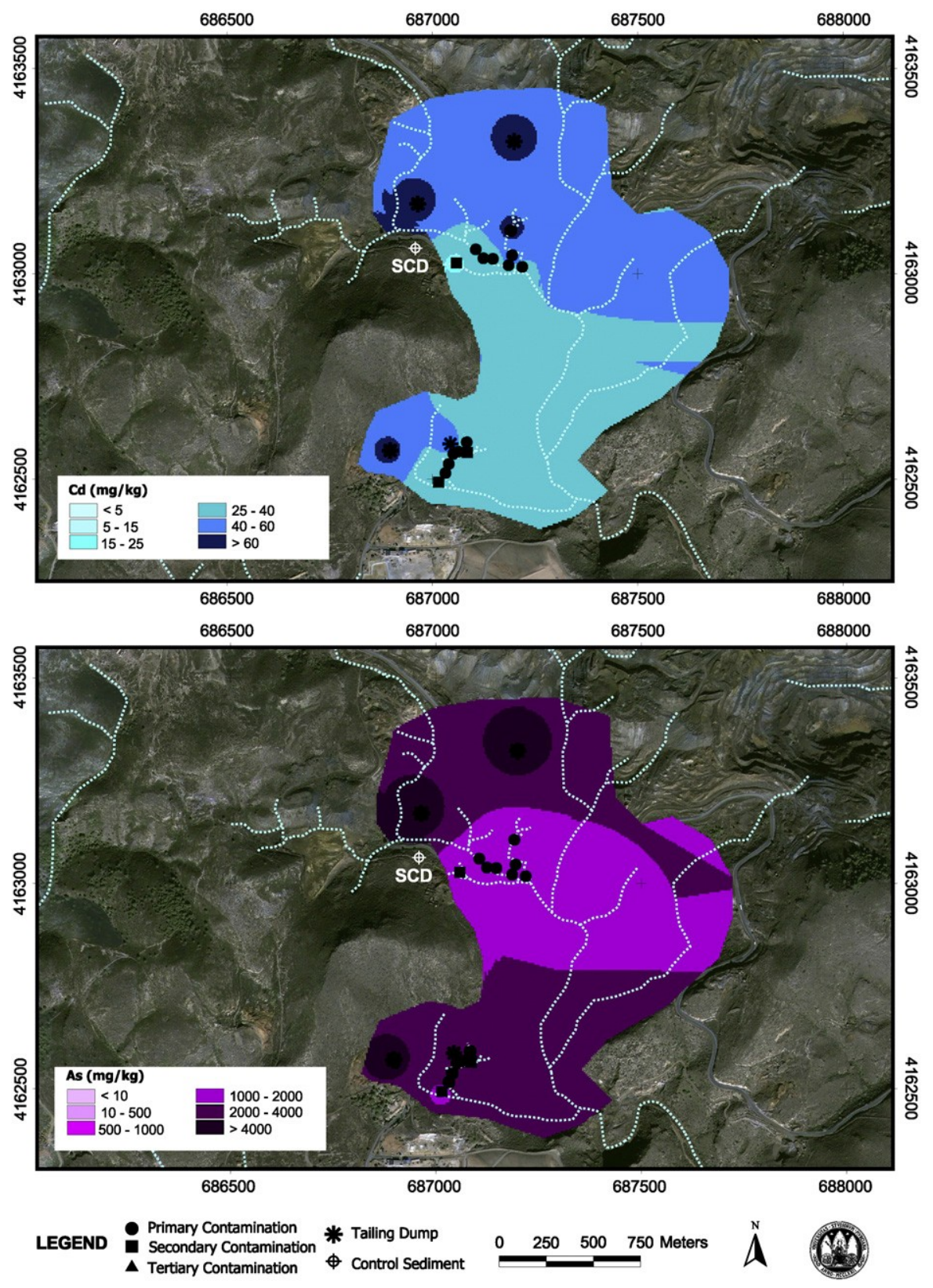

Fig. 11. Spatial distribution of Cd and As in Zone D.

As a consequence, attenuation processes of trace element contami- nation take place due to acid neutralisation, which cause trace element precipitation, and also due to a dilution effect, which could also attenuate metal concentration.

\subsubsection{Trace element dispersion conceptual model in Zone B}

In this area trace elements are transported from tailing dumps, mainly in aqueous solution by ephemeral watercourses (Figs. 6 and 7). Points located close to tailing dumps are affected by primary contamination. During transport, a natural attenuation process takes place, and some elements could precipitate as hydroxide, oxyhydroxide, or hydroxysulfate phases. In addition, and as we explained before, a dilution process could also attenuate metal concentration.

\subsubsection{Trace element dispersion conceptual model in Zone $C$}

All the sampling points collected in Zone $\mathrm{C}$ are affected by primary contamination, because there are a lot of tailing dumps and sampling points are located close to them (Figs. 8 and 9). Then, this area could be considered as a big contamination source.

\subsubsection{Trace element dispersion conceptual model in Zone D}

In Zone $\mathrm{D}$, almost all sediments are affected by primary contamination, because sampling points are located close to tailing dumps. In this area, trace element contamination is attenuated by mixing with surrounding materials and by dilution effect (Figs. 10 and 11).

\section{Conclusions}

Mining activities in the Sierra Minera of Cartagena-La Unión have produced great amount of wastes, characterised by high trace element content, acidic $\mathrm{pH}$ and minerals from supergene alteration. Trace elements in the studied area could be dispersed, both downstream and downslope from the mine, possibly due to surface run-off and strong winds. Hydric dispersion patterns of trace elements vary depending on 
their mobility. Trace element hydric mobilisation could take place during the rainy season, an important pollution route in the studied area. Trace elements could be mobilised if they are present as soluble species in the aqueous solution.

Oxides and hydroxides of iron and manganese, hydrated sulphates and jarosites are the main products of weathering of the superficial materials affected by primary contamination. The most important processes involved in trace element mobilisation and dispersion are oxidation-reduction, together with dissolution and evaporation processes.

Natural attenuation process takes place when parent material is capable of buffering drainage. A primary control on the process of metal attenuation is acid neutralisation. As $\mathrm{pH}$ increases, aqueous metal species tend to precipitate. Trace elements may also be able to be adsorbed, removing trace elements from solution. In addition, simple dilution could attenuate trace element concentration. It is important to highlight that these barriers could act as secondary contamination sources in case of their destabilisation.

\section{Acknowledgements}

The authors also are grateful to Spanish Ministerio de Educación y Ciencia (CTM2008-04567). Mari Luz García-Lorenzo also acknowledges a fellowship from Fundación Séneca.

\section{References}

AFNOR, 1993. Norme française NF X 31-109. Qualité des sols. Méthodes chimiques. Détermination du carbone organique par oxidation sulfochromique.

Asta, M.P., 2011. Procesos geoquímicos en aguas ácidas por meteorización de sulfuros. Boletín Geológico y Minero 122 (2), 259-272.

Banks, D., Younger, P.L., Arnesen, R.-T., Iversen, E.R., Banks, S.B., 1997. Mine-water chemistry: the good, the bad and the ugly. Environmental Geology 32, 157-174.

Berger, A.C., Bethke, C.M., Krumhansl, J.L., 2000. A process model of natural attenuation in drainage from a historic mining district. Applied Geochemistry 15, 655-666.

Bhattacharya, A., Routh, J., Jacks, G., Bhattacharya, P., Mörth, M., 2006. Environmental assessment of abandoned mine tailings in Adak, Västerbotten district (northern Sweden). Applied Geochemistry 21, 1760-1780

Chapman, B.M., Jones, D.R., Jung, R.F., 1983. Processes controlling metal ion attenuation in acid mine drainage streams. Geochimica et Cosmochimica Acta 47, 1957-1973. Chopin, E.I.B., Alloway,

B.J., 2007. Distribution and mobility of trace elements in soils and vegetation around the mining and smelting areas of Tharsis, Ríotinto and Huelva, Iberian Pyrite Belt, SW Spain. Water, Air, and Soil Pollution 182, 245-261.

FAO-UNESCO, 1990. Soil Map of the World — Revised Legend. FAO, Rome.

García-García, C., 2004. Impacto y riesgo ambiental de los residuos minero- metalúrgicos de la Sierra de Cartagena- La Unión (Murcia, España). PhD Thesis. University of Cartagena, Murcia, Spain.
García-Lorenzo, M.L., 2009. Evaluación de la contaminación por vía hídrica de elementos traza en áreas con influencia de actividades minero-metalúrgicas. Aplicación a la Sierra Minera de Cartagena- La Unión (Murcia). PhD Thesis, University of Murcia, Spain.

Gomes, M.E.P., Favas, P.J.C., 2006. Mineralogical controls on mine drainage of the abandoned Ervedosa tin mine in north-eastern Portugal. Applied Geochemistry 21, 1322-1334.

Kimball, B.A., Broshears, R.E., McKnight, D.M., Bencala, K.E., 1994. Effects of instream pH modification on transport of sulfide-oxidation products. Environmental Geochemistry of Sulfide Oxidation. American Chemical Society, pp. 224-243.

Lee, C.H., 2003. Assessment of contamination load on water, soil and sediment affected by the Kongjujiel mine drainage, Republic of Korea. Environmental Geology 44, 501-515.

Lottermoser, B.G., 2007. Mine Wastes Characterization, Treatment, Environmental Impacts, 2nd ed. Springer, Berlin. ed.

Martín, D., 2004. Qualitative, quantitative and microtextural powder X-Ray diffraction analysis. http://www.xpowder.com.

Martínez-Sánchez, M.J., Navarro, M.C., Pérez-Sirvent, C., Marimón, J., Vidal, J., García- Lorenzo, M.L., Bech, J., 2008. Assessment of the mobility of metals in a mining- impacted coastal area (Spain, Western Mediterranean). Journal of Geochemical Exploration 96, 171-182.

Moreno, T., Oldroyd, A., Mcdonald, I., Gibbons, W., 2007. Preferential fractionation of trace metals-metalloids into PM10 resuspended from contaminated gold mine tailings at Rodalquilar, Spain. Water, Air, and Soil Pollution 179, 93-105.

Navarro, A., Collado, D., Carbonell, M., Sánchez, J.A., 2004. Impact of mining activities on soils in a semi-arid environment: Sierra Almagrera district, SE Spain. Environmen- tal Geochemistry and Health 26, 383-393.

Navarro, M.C., Pérez-Sirvent, C., Martínez-Sánchez, M.J., Vidal, J., Tovar, P.J., Bech, J., 2008. Abandoned mine sites as a source of contamination by heavy metals: a case study in a semiarid zone. Journal of Geochemical Exploration 96, 183-193.

Nelson, D.W., Sommers, L.E., 1982. Total carbon, organic carbon, and organic matter. In: Page, A.L., Miller, R.H., Keeney, D.R. (Eds.), Methods of Soil Analysis. Soil Science Society of America, Madison, pp. 539-579. Part 2 .

Nordstrom, D.K., 1982. The effect of sulfate on aluminum concentrations in natural waters: some stability relations in the system $\mathrm{Al}_{2} \mathrm{O}_{3}-\mathrm{SO}_{3}-\mathrm{H}_{2} \mathrm{O}$ at $298 \mathrm{~K}$. Geochimica et Cosmochimica Acta 46, 681-692.

Pérez-Sirvent, C., Martínez-Sánchez, M.J., García-Lorenzo, M.L., Molina, J., Tudela, M.L., 2009. Geochemical background levels of zinc, cadmium and mercury in anthro- pically influenced soils located in a semi-arid zone (SE, Spain). Geoderma 148, 307-317.

Rajamani, V., Tripathi, J.K., Malviya, V.P., 2009. Weathering of lower crustal rocks in the Kaveri river catchment, southern India: implications to sediment geochemistry. Chemical Geology 265, $410-419$.

Robles-Arenas, V.M., Candela, L., 2010. Hydrological conceptual model characterisation of an abandoned mine site in semiarid climate. The Sierra de Cartagena-La Unión (SE Spain). Geologica Acta 8, 235-248.

Rodríguez, L., Ruiz, E., Alonso-Azcárate, J., Rincón, J., 2009. Heavy metal distribution and chemical speciation in tailings and soils around a $\mathrm{Pb}-\mathrm{Zn}$ mine in Spain. Journal of Environmental Management 90, 1106-1116.

Sun, Y., Xie, Z., Li, J., Chen, Z., Naidu, R., 2006. Assessment of toxicity of heavy metal contaminated soils by the toxicity characteristic leaching procedure. Environmen- tal Geochemistry and Health 28, 73-78.

Swingedouw, C. Crépin, J.M., 2008. Sampling methods for site characterization. In: De Vivo, B., Belkin, H.E., Lima, A. (Eds.), Environmental Geochemistry: Site Character- ization, Data Analysis and Case Histories. Elsevier, Amsterdam, pp. 13-27. 